\title{
Catatan Baru Persebaran Pinang Gajah (Nenga gajah J. Dransf.)
}

\section{Di Sumatra}

\author{
Joko R. Witono ${ }^{1}$, Sutrisno ${ }^{1}$, \& Inggit Puji Astuti ${ }^{1}$
}

Pusat Konservasi Tumbuhan-Kebun Raya Bogor, LIPI, Jl. Ir. H. Juanda 13, Bogor, 16122

e-mail:jrwitono@yahoo.com,witono@hiroshima-u.ac.jp.*Penulisuntuk korespondensi

Sumatra merupakan salah satu pulau besar di kawasan Malesia Barat yang memiliki keanekaragaman palem yang tinggi. Menurut Uhl \& Dransfield (1987), di Sumatra terdapat 26 marga palem, salah satu diantaranya adalah Nenga. Nenga terdiri atas 5 jenis, yaitu Nenga gajah, N. pumila, N. banaensis, N. macrocarpa, dan N. grandiflora (Fernando, 1983). Kelima jenis tersebut tumbuh pada daerah hutan hujan tropika pada ketinggian antara $0-1.400 \mathrm{~m} \mathrm{dpl}$. Daerah persebarannya di Asia Tenggara mulai Thailand, Semenanjung Malaya, Sumatra, Jawa, dan Kalimantan. Satu-satunya jenis Nenga yang dinyatakan sebagai jenis endemik, sekaligus langka adalah Nenga gajah (WCMC, 1996) karena populasinya yang sangat rendah dan terancam oleh aktivitas perladangan liar dan perluasan kebun kopi rakyat.

Nenga gajah yang dikenal dengan nama pinang mancung (Sumatra Barat, Riau), pinang gajah (Bengkulu), muring gejoh selasih dan muring gejoh putih (Jambi) ini, dipertelakan pertama kali oleh Dr. John Dransfield (1975) berdasarkan herbarium dari Kapahiang, Bengkulu (Dransfield 1234, 12 Pebruari 1971). Type jenis tersebut tersimpan di Herbarium Bogoriense (BO), isotypenya disimpan di Herbarium Bailey Hortorium (BH), Herbarium Kew (K), dan Herbarium Leiden (L). Pada tanggal 27 Agustus 1973, Dr. John Dransfield melakukan ekspedisi pada tempat yang sama (Dransfield 3625). Di lokasi tersebut, Nenga gajah tumbuh pada lereng bukit yang terjal dan di tepi sungai kecil pada ketinggian 800-850 m dpl. Koleksi Nenga gajah juga dibuat oleh H.A.B. Bunnemeijer (1917) saat melakukan ekspedisi ke Gunung Talakmau di lereng timur laut, Bukittinggi, Sumatra Barat (Bunnemeijer 295, 296, 417, 1013 ). Sejak itu persebaran Nenga gajah hanya diketahui dari kedua daerah tersebut.
Ciri-ciri spesifik Nenga gajah adalah sebagai berikut : tumbuh tunggal, berbatang pendek, memiliki akar gantung, tinggi batang sampai $2,5 \mathrm{~m}$, diameter $15-17 \mathrm{~cm}$, ruas pendek (kurang dari $1 \mathrm{~cm}$ ), kulit batang coklat keabuabuan. Jumlah daun pada tajuk 8-10 buah. Tajuk pelepah tertutup oleh daun kering yang persisten, pelepah sampai $60 \mathrm{~cm}$, hijau kekuningan, panjang tangkai daun $50-75 \mathrm{~cm}$, diameter $2,5 \mathrm{~cm}$, berwarna coklat tua. Anak daun teratur, terdiri dari 8-27 helai di tiap sisinya, anak daun bagian tengah lebih lebar daripada bagian pangkal maupun ujung, berbentuk pita, ukuran $60 \times 8 \mathrm{~cm}$. Perbungaan di interfoliar (diantara pelepah daun), pangkal tegak, ukuran $25-33 \times 4 \mathrm{~cm}$, berkayu dan berserat, tertutup oleh bulu-bulu berwarna coklat terutama di bagian tepi, berbentuk malai, panjang $30-40 \mathrm{~cm}$, rakila $3-5$ yang berukuran $10-12 \mathrm{~cm}$, bagian pangkal rakila hanya terdapat bunga jantan, di ujung rakila terdapat bunga jantan maupun betina. Daun penumpu berbentuk pita, ukuran $25 \times 4 \mathrm{~cm}$. Bunga jantan terletak pada 2-4 rakila yang terdekat dengan pangkal / perbungaannya. Bunga betina terletak di pangkal rakila terujung. Perbuahan menggantung, biasanya terdapat di bagian ujung. Buah lonjong, $5-8 \times 1,5-2,5 \mathrm{~cm}$, pangkal dan ujung lancip, warna coklat keunguan. Biji berbentuk bulat telur, panjang sampai $4,5 \mathrm{~cm}$ dan diameter $1,8 \mathrm{~cm}$, meruncing pada bagian ujung dan membulat pada bagian pangkal.

Nenga gajah memiliki karakter morfologi yang berbeda dibandingkan dengan jenis Nenga yang lain, karena perbungaannya interfoliar (di antara daun), tegak, memiliki tangkai perbungaan yang panjang dan daun yang kering umumnya persisten (tetap menempel pada batang meskipun telah kering). Sedangkan jenis Nenga yang lain perbungaannya infrafoliar (tumbuh di bawah tajuk pelepah) seperti pada Pinanga dan Areca, 
menggantung, tangkai perbungaan pendek, dan daun kering akan segera luruh.

Nenga gajah memiliki karakteristik habitat yang khas, karena hanya tumbuh pada lerenglereng bukit yang curam dan tepi aliran sungai kecil pada pertemuan antara 2 kaki bukit pada hutan dataran rendah Dipterocarpaceae. Palem ini tumbuh membentuk suatu kelompok kecil di lantai hutan dengan tegakan pohon yang masih rapat. Penulis tidak pernah menemukan tumbuh pada tempat-tempat yang terbuka atau di hutan sekunder. Hal ini mungkin disebabkan karena palem ini tidak mampu beradaptasi pada lingkungan yang demikian.

Pemencaran biji diduga dilakukan oleh air (air hujan atau sungai), karena di lapangan populasi yang besar hanya ditemukan di tepi sungai yang mengalir perlahan. Hewan diduga tidak berperan menyebarkan biji pinang gajah, karena belum ada keterangan atau bukti mengenai jenis binatang yang makan dan memindahkan buah palem ini. Menurut masyarakat setempat, kancil sangat menyukai daging buah palem ini, namun hal yang dapat membuktikan belum diketahui.

Berdasarkan hasil ekspedisi yang dilakukan terakhir, Nenga gajah memiliki daerah persebaran yang lebih luas, karena jenis tersebut dapat pula ditemukan di Taman Nasional Bukit Tigapuluh, Seberida, Riau (Witono \& Walters, 2000) dan Taman Nasional Bukit Duabelas, Sorolangun, jambi (Astuti \& Sutrisno, 2001).

Di Taman Nasional Bukit Tigapuluh, Seberida, Riau, Nenga gajah terdapat di hutan dataran rendah dipterocarpaceae pada ketinggian $150 \mathrm{~m}$ dpl. Populasi yang besar ditemukan pada sungai kecil yang mengalir perlahan pada pertemuan dua bukit. Jenis ini berasosiasi dengan jenis palem yang lain, seperti Iguanura wallichiana dan Pinanga malaiana. Pada saat penulis melakukan ekspedisi di daerah tersebut, $N$. gajah ditemukan pada saat berbuah muda dan berwarna hijau keunguan.

Di Taman Nasional Bukit Duabelas, Sorolangun, Jambi, Nenga gajah terdapat di hutan dataran rendah dipterocarpaceae pada ketinggian $180 \mathrm{~m}$ sampai $240 \mathrm{~m} \mathrm{dpl}$. Palem ini ditemukan pada tepi sungai kecil yang termasuk dalam wilayah bukit Pal. Di daerah tersebut, ditemukan adanya variasi dalam warna buah muda, yaitu spesies yang warna buahnya hijau keunguan (muring gejoh selasih) dan hijau (muring gejoh putih). Perbedaan warna buah tersebut diduga disebabkan karena perbedaan iklim mikro tempat tumbuh palem tersebut. Berdasarkan tipe, warna buah masak Nenga gajah coklat keunguan, sehingga penulis yakin bahwa buah N. gajah dari TN. Bukit Duabelas akan berwarna coklat keunguan jika telah masak. Hal ini didasarkan pada karakter morfologinya yang sama dengan type yang berasal dari Kapahiang, Bengkulu. Menurut catatan penulis, populasi muring gejoh selasih dan muring gejoh putih dipisahkan oleh perbukitan berjarak sekitar $4 \mathrm{~km}$. Adanya informasi baru mengenai daerah persebaran Nenga gajah tidak menutup kemungkinan spesies tersebut juga dapat ditemukan di kawasan lainnya.

\section{Daftar Pustaka}

Anonim. 1995. WCMC Plants Programme. World Conservation Monitoring Centre.

Astuti, I.P. dan Sutrisno. 2001. laporan Ekplorasi Flora di Taman Nasional Bukit Duabelas, Jambi. UPT Balai Pengembangan Kebun Raya Bogor-LIPI (tidak dipublikasikan).

Dransfield, J. 1975. A Remarkable New Nenga from Sumatra. Principes 19: 27-35.

Fernando, E.S. 1983. A Revision of the Genus Nenga Principes 27(2): 55-70.

Uhl, N.W. and Dransfield, J. 1987. Genera Palmarum, a Classification of Palms based on the Work of H.E. Moore Jr. The Bailey Hortorium \& The International Palm Society, Kansas.

Witono, J.R. dan Walters, T.W. 2000. Laporan Ekspedisi Palem di Taman Nasional Kerinci Seblat dan Taman Nasional Bukit Tigapuluh. UPT Balai Pengembangan Kebun Raya-LIPI, Bogor bekerjasama dengan Montgomery Botanical Center, Miami, Florida (tidak dipublikasikan). 